\title{
THE MISSIONARY OCCUPATION OF THE SOUTHERN SUDAN
}

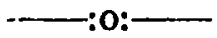

THE urgent nature of the crisis in the Anglo-Egyptian Sudan has recently been brought home to me by a trip through North-east Africa, from Alexandria to Mombasa. The journey southward to Khartoum reveals a pathetic picture of the trimphant advance of Islam and a woeful lack of Christian missionary enterprise among the pagan Nilotic tribes. For hundreds of miles at a stretch, among semi-pagan and wholly pagan tribes, there is a total absence of missionary work, and the inevitable consequence is everywhere apparent,--Islam is making unopposed progress through the country and so rendering future missionary work incalculably more difficult. The small number of missionaries who are at present in the field is utterly inadequate for the task of checking this Moslem advance. There should be at least five times as many as there are at present if such scattered tribes as the Dinka and Shilluk people are to be evangelized. The field is hopelessly undermanned.

The excuse often urged for this unoccupied state of the Sudan is a government regulation regarding Christian missions which, it is supposed, prohibits mission work throughout the whole Sudan. But while this may or may be not true regarding Khartoum and the northern Sudan, it certainly does not apply to the southern and pagan part of the country. Indeed, so far is it from being the case, that the Government expressly invited missionary co-operation, a few years ago, in the work of civilizing and educating the people; and at the present time by granting half fares on the steamers and trains, and by giving other concessions to missionaries, the Government is greatly helping the work of those societies whose representatives are in the field. But 
despite this invitation to undertake missionary work, and despite the facilities afforded, the country has an utterly insufficient force to do the work of winning the people to Christ.

The actual figures relative to the numbers and distribution of mission stations and workers south of Khartoum are as follows: For the first four hundred odd miles Islam has undisputed liberty to expand and become rooted, there being no mission station in that huge territory, although there are a great many pagan and semi-pagan people there. Then at Melut, 420 miles south of Khartoum, is situated the recently opened Sudan United Mission station, in connection with the establishment of which my trip through the country was undertaken. This station has at present a staff of only three men, but it is hoped that others will shortly arrive to augment that number. Then southward again for another 100 miles, and one sees the American United Presbyterian station at the junction of the Sobat and the Nile. Here, including the missionaries at an out-station, there is a force of seven. South of the mouth of the Sobat, and on the Nile, there is another great gap of about 200 miles, when the C.M.S. station of Malek is reached. Here there are four missionaries. This is the last Protestant mission station in the Sudan on the Nile, there being a gap to the south of some 300 miles before the C.M.S. station of Gulu in Uganda is reached. West of the Nile and in the Bahr el Ghazal province of the Sudan, are two C.M.S. stations at Zau and Yambio, with a force of four men between them. Besides these Protestant stations, there are on the west bank of the river three Austrian Roman Catholic missions, but I do not know their total number of workers. Thus the Protestant missionary force in this most important and strategic region total eighteen in all, only about twothirds of whom can ever be in the field at the same time!

Relative to the population of the Sudan this number of missionaries is perhaps as great, or greater, than the number in certain parts of China, India and Japan, but the present population of a particular region or courtry 
is by no means the only consideration to be taken into account in the distribution of our forces. The nature of the people and their religion, the relation of that country or region to other countries, and its accessibility to the Christian world, must also be considered. On all these grounds the situation in the Sudan challenges our most earnest attention.

(1) The Nilotic tribes are simple people, like children in many respects, and are easily impressed by show and force, unless animated by religious fanaticism, which, as pagans, they never are. Their religion is a primitive one, which quickly gives way to any more dogmatic teaching than its own. Indeed, those who know most about Africa assure us that the days of paganism are numbered, and that it must crumble away in the near future before any more dogmatic or seemingly authoritative religion that comes into conflict with it. If a sufficient number of Christian mission stations were planted among these people while they are yet pagan and in a comparatively plastic condition, there would be great hope-not, perhaps, of winning them to Christ in one generation, but at least of checking the progress of Islam by showing the pagans that there are other religions than Islam in which civilized people believe. At the present time it appears to the pagan that all the educated, rich and powerful people are Moslems, and the poor and oppressed are, like himself, of no religion. If a pagan who lives near a Moslem settlement is asked whether he is a Moslem, he says "Yes" at once. Why ? Because he is a Moslem ?' No! He is no more a Moslem than his questioner: he merely says "yes" because he thinks that all the seemingly rich and powerful foreigners from the north are Moslems, and he too wants to be rich and powerful and wise. It is not so much the moral license of Islam that first attracts the pagan, for he probably never learns what Islam allows or prohibits; it is the clothes and the wealth and the apparent wisdom of the Moslem that he covets. He calls himself a Moslem because that is the highest thing he has ever heard of. But it is only a step between calling himself a Moslem and becoming a Moslem and training his family in 
Islam. If, then, there were more evidences of Christianity, this impressionable pagan would turn to Christianity as easily as to Mohammedanism; he might be as poor a Christian convert as he is now a convert to Islam, but at least he would not be a bigoted opponent of Christianity, and something more might be done with his children.

(2) With regard to the relation of the Anglo-Egyptian Sudan to the countries to the west, south and east of it: on the west is the French Sudan, partly Moslem and partly pagan : on the south lies the Belgian Congo and the Uganda Protectorate, where a native church is already grappling with a Moslem advance from the south-east : on the east lies Abyssinia, in which a nominal Christianity has almost let its light die out. What, then, will be the effects on these neighbouring countries if we allow the southern Sudan to become wholly or predominantly Moslem? A great impetus would be given to the spread of Islam in the Congo and the French Sudan, the already complex problems of Uganda would be greatly increased, and Abyssinia would be filled with Moslem traders eager to spread their victorious faith.

(3) The accessibility of the Sudan: No country could be more accessible. Khartoum is only nine dajs' journey from London! It is the nearest heathen field to Christian Europe, and yet it has only eighteen missionaries working there. From Khartoum several steamers run southward each month, branching at the Sobat and Lake No, to the various streams of the Upper Nile. Throughout the length and breadth of the country runs the finest navigable waterway in the world, but while this great river brings food and life to Egypt, it bears only merchandise and Islam to the south.

I would plead with those who may chance to read this article for a great outpouring of prayer for the pagan tribes of the Sudan, and for an active interest in the work of extending the Kingdom of God in that neglected region.

Melbourne,

D. N. MacDiarmm. Australia. 